\title{
Secondary School Students' Perceptions on the Use of Google+ towards Improving ESL Writing Skills
}

\author{
https://doi.org/10.3991/ijet.v13i09.8479 \\ Maslawati Mohammad( $\left.{ }^{\bowtie}\right)$, Naiman Ghazali, Harwati Hashim \\ Universiti Kebangsaan, Malaysia \\ maslawati@ukm. edu.my
}

\begin{abstract}
The use of social media in teaching has also revolutionized the way learning takes place. At higher education levels, measures have already been taken in incorporating the use of social media for learning purposes especially in the teaching of language. However, at secondary school levels, educators are still having doubts about using social media due to multiple issues. Thus, this study was conducted to investigate the perceptions of secondary school students and a teacher in Malaysia on the use of Google+ towards the teaching of ESL writing skills. A case study method was adopted to carry out this research. Twelve secondary school students volunteered to participate in this study. Data were collected through focus group interview on the students and an individual interview with the class teacher and field notes. The overall findings of the study are that participants had positive perceptions on the usage of Google+ towards ESL writing. They gained a number of benefits, which include: having enjoyable and attentive lessons through the interactive features of Google + , as well as engaging themselves in an active and interesting lesson. The participants felt that they were having a sense of purpose, thus becoming more engaged in the writing tasks. As for interaction, the participants were interacting more confidently in Google+ writing classes compared to conventional writing lessons. The implication derived from this study is that teachers need to be made aware of how to integrate social media as learning tools in the teaching of English as a Second Language (ESL), particularly, in the teaching of ESL writing to upper secondary school students.
\end{abstract}

Keywords - perceptions, Google+, Web 2.0, Writing Skills, English as Second Language (ESL), secondary school students

\section{Introduction}

Technology has changed the way people communicate and manage their daily lives. In this age of technology, it is very important for people to keep themselves updated and also learn how to adapt with the latest updates in technology. Technology such as social media has taken over the world in a short time where people are linked through social media apps [1]. Apart from connecting people and promoting business products, social media has also been used to support learning [2] and teaching [3]. Learning can take place anywhere as long as we are equipped with the right tool and 
know how to use it appropriately. Students can now enjoy the excitement of learning as the lesson is now beyond the four walls [4]. The students can also get connected with other people from around the globe and share their thoughts and ideas. Teachers can now use social media to gauge the students in a way better than what they could have possibly done before. Studies conducted by PEW Research Centre on the use of digital tools on students' writing suggest that teachers view positively the impact of the internet and digital technologies on students [5].

Investigations of potential technology in helping ESL students in writing skills such as Technology Enhanced Language Learning (TELL), Computer Assisted Language Learning (CALL), e-learning and mobile learning [6] suggest that they provide 'limitless possibilities'. With respect to writing in particular, the novelty and innovation that technology brings along with it, may encourage second language students to think of writing in English in new and positive ways as compared to writing in nontechnology environments [7].

In the last few decades, we have seen 'the introduction of technology in its varied forms in language education [7], for examples, language learning via Internet through multimedia learning, online learning, Web-based learning, ICT, Computer-Mediated Communication (CMC), Technology Enhanced Language Learning (TELL) and most recently the use of social media in language learning. Social media for higher education is apparently changing the nature of the students who are entering university [8]. Most of the technologies mentioned are commonly used at tertiary level, however, fewer are used at secondary level particularly in a developing country like Malaysia. If these technologies have a positive impact at tertiary level, there is a need to explore how these technologies can be adapted at secondary level. In Malaysia, ICT was found to be less applied in the teaching of English as a Second Language (ESL) at secondary schools, and there were some negative views which stated that using ICT for teaching material is a waste of time [9].

In line with teaching in the $21^{\text {st }}$ century, technology is an important issue in many fields including education [10].

Currently, people all over the world are connected through technology tools and equipment as it appears to be the main medium of connectivity [11] [12]. Google ${ }^{+}$has been proven to be a worthy investment at the higher institution of learning. For example, a project conducted by The University of Derby has enabled cost effective innovative collaboration and comparative student learning with the utilisation of a freely accessible online platform [13]. The same initiative should be implemented at secondary school level.

The Malaysian government has invested a lot of money to upgrade ICT facilities in schools [14], therefore, there is a need to study how the use of such technology could be optimised in the classrooms at secondary schools. The lack of studies carried out on Google+ at secondary level has encouraged the researchers to conduct a study in this area at a local context and to fill the gap regarding the use of Google+ in the teaching of ESL writing at secondary school level in Malaysia. The research objective of this study is to identify the perceptions of both parties, the teacher and students, towards the use of Google+ in improving secondary school students' writing skills. 


\subsection{The Integration of ICT in Malaysian Schools}

The use of ICT in Malaysian schools has started since the introduction of the Smart School Program. This program was under the flagship of Multimedia Super Corridor which was launched by our former Prime Minister Tun Dr Mahathir Mohamed in 1995 [14]. Teachers have been supplied with courseware and software that could be used to support learning especially in the teaching of English in class. Teachers were expected to a obtain certain level of ICT knowledge in order to guide their students in an ICT integrated learning environment. The introduction of the teaching of Mathematics and Science in English further developed teachers' knowledge and skills to use ICT in their teaching and learning process. Most of the schools in Malaysia are now sufficiently equipped with Internet connection, LCD projectors and also computers [15] In order to ensure that our country is not left behind in terms of technology, trainee teachers are trained to use technology tools before they are posted into the actual teaching in schools. The latest update in curriculum development and government policies is seen to be giving ICT development programs a positive impact. Malaysia has already passed the two critical stages in implementing the integration of ICT and is now at the stage of consolidating and stabilizing this integration. The aim set by the Ministry under the 7th shift in the new Malaysian Education Blueprint (MEB) 2013-2025 is "leverage ICT to scale up quality learning across Malaysia" [16].

English as a Second Language in Malaysian Schools. Meanwhile, the establishment of the English language as the second national language in Malaysia has gone through a lot of transformation. Be it at the primary school level, secondary school level and also at tertiary education level. The move to strengthen the proficiency level of the students has taken place through several policies carried out by the Ministry of Education. English is a compulsory subject taught at all levels of education. The teaching of English in Malaysian schools emphasizes rote learning and the mastery of specific language skills that are tested via examinations [17]. Writing skills are an important aspect of academic performance [18]. However, writing has always been a difficult area for second language students and a hot topic for second language researchers [19]. Writing in second language is a complex process of discovery [20]. It involves brainstorming, multiple drafting, feedback practices, revision and final editing. Writing also enhances the language acquisition as students experiment with words, sentences and larger chunks of writing to communicate their ideas effectively and to reinforce the grammar and vocabulary they are learning in class [21].

\section{$2 \quad$ Literature Review}

\subsection{Web 2.0 Technology}

Based on [22], 'Web 2.0' is a term which is referring to a host of Internet applications such as social networking, wikis, folksonomies, virtual societies, blogging, multiplayer online gaming and 'mash-ups'. Despite of its various forms and functions, all these applications share a common characteristic of supporting Internet-based interac- 
tion between and within groups, which is referred as 'social software'. This 'social software' or interchangeably referred as 'social media' is often used to describe Web 2.0 tools and services. One of the major characteristics of 'social media' is the element of sociability in some sense, thus provide a platform and opportunities for collaboration among users. It also includes some forms of user generated content, personalisation, and social interaction which can be utilised among academia to facilitate learning.

The growing availability of high-speed Internet access further added to the popularity of the concept, leading to the creation of social networking sites such as [23] and [24]. This, in turn, coined the term "Social Media" and contributed to the prominence it has today. [1] consider Web 2.0 as the platform for the evolution of Social Media. They further explain that "User Generated Content (UGC) can be the sum of all ways in which people make use of social media". UGC fulfils three basic requirements as it needs to be published either on a publicly accessible website or on a social networking site accessible to a selected group of people; second, it needs to show a certain amount of creative effort and finally, it needs to have been created outside of professional routines and practices. Web 2.0 that is being referred to in this study is mainly social media applications.

\subsection{Google+ tools for teaching writing skills}

Technology has always been the catalyst in improving the teaching and learning process in the classroom. In the context of ESL classrooms, the use of technology not only allows students to quickly master new language skills through exposure to a variety of new methods, but also brings with it the excitement of a new medium that could motivate the students for an extended period of time [25]. As we move to the $21^{\text {st }}$ century, technology in the classroom has been a dominant factor in ensuring students' ease of learning. The advancement in Information Technology (IT) continues to evolve and change rapidly over the past few decades. The art of learning, acquiring and dispersing knowledge and information has also continued to evolve rapidly. These rapid innovations and improvements in IT were designed with the aim of boosting knowledge and education at just the click of the button. The introduction of Web 2.0 has spawned some of the most outstanding innovations and inventions in the IT world, which have influenced education. Learning in this decade is found in the social networks such as Yahoo, Google, Facebook, Twitter, and YouTube.

Recent studies conducted with regards to Web 2.0 revealed that these current innovations and advancements in IT have constituted challenges to the knowledge and learning process [26]. In this century, during the process of seeking to transfer knowledge to their students, educators are often faced with a dilemma in finding the best way to engage their students within and outside the classroom environment. The Internet and Web 2.0 have also improved the way we learn from the past. In the beginning, users of the Internet could only read what was posted on the portal. With Web 2.0, students have the ability to read and write content on the Internet. Dominant on the World Wide Web, Google has transformed itself to be the world's largest search engine. Despite its role as the main player in the World Wide Web industry, 
Google has also contributed to education. Due to the advantage Google has in comparison to other World Wide Web applications, the researchers selected Google + to embark on the study.

\subsection{Google+}

Google+ is Google's latest attempt at social networking. It offers a unique way of connecting with various contacts, allowing the users to send group messages to particular social circles they designate. Google+ is a platform in which users communicate. The users can find and add friends, find and follow companies, entertainers, politicians, and others. They can create profiles with information about personal interests, job history, education, and location. Furthermore, they can create and share photo albums, status updates, and events. The element that makes Google+ even more interesting is that the users can share videos and links to online articles. They can also send instant messages and private messages and post messages to public friends. Playing online games, video chats and video conference for free are among other uses of Googlet. The users can control the information they share by using privacy settings, and they can also "check in" to physical places online. For business, the users can create free pages. Finally, they can search Google+ public posts to see what other users are sharing about any given topic [27]. This social network is a collection of different social products. These features include Stream (newsfeed), Sparks (a recommendation engine), Hangouts (a video chat service), Circles, games and photos. For the purpose of this study, the writing lesson is taught using Google+ platform.

\subsection{The advantages and disadvantages of using Google+ for the teaching and learning of writing skills}

Social media enhances peer interactions, bridge diversity in the classroom and establishes open lines of communication between students and educators. They enhance outside classroom interaction and education among the students and between the students and the teacher [28] [29]. Moreover, it facilitates discussions and knowledge transfer among students, as well as creating deeper sense of understanding course materials [30]. It provides a large amount of information that can be shared between the teacher and students and among students themselves [28] [29]. The use of Blogs facilitates the development of students' writing skills [31] [28]. Students have positive attitudes towards using Facebook as a means of learning grammar and writing [32]. The use of social network services train students' thinking skills and writing skills [28] Social networking websites also encourage students to listen and produce their own materials [33].

Furthermore, as students show a higher level of comfort using Facebook, it helps them in increasing the quality and the efficiency of communication between students and instructors [34]. Social networking services increase motivation and build confidence for students in using and learning English, help students to build and improve their vocabulary and provide a platform for teachers to prepare the lesson efficiently such as pre-writing preparation [28] [29]. Twitter was found to have great potential in 
making educational experiences engaging, fun and interactive for students [35] [36]. In addition, social networking also enhances outside classroom interaction between teachers and students, broadens students' knowledge, increases motivation and confidence, and also helps in improving their vocabulary skills [28] [29].

However, despite the advantages that social media brings, some disadvantages were found in the findings. It is true that a social networking site can provide opportunities for language interaction. Nevertheless, participants could develop indifference to the technology [37]. Most college students were found to have spent many hours on social media that could bring about negative effects [38]. Moreover, teachers also need to reconsider their roles as teachers as well as their affective and attitudinal effects on social media used for education [39].

\section{$3 \quad$ Methodology}

This study employed a qualitative design. The research instruments are semistructured focus group interview, field notes and an individual interview to obtain the teacher and students' perceptions on the use of Google ${ }^{+}$towards improving ESL writing skills.

The participants were selected through purposive sampling. The selection criteria were that the upper secondary school students should enrol in English lessons which employed Google+ in their writing lessons. Only 12 students enrolled in this class. All these 12 students volunteered to participate in the focus group interview. The teacher who taught this class was interviewed. The researchers also produced field notes. The field notes are based on the researchers' observations on the English lessons using Google+. The respondents' English language proficiency is intermediate. Their age range is between 16-17 years.

The semi structured interview questions (Appendix A) were given to two experts to be reviewed focusing on a few aspects namely clarity, redundancy, readability and completeness. The experts were experienced school teachers who taught English to upper secondary school students for a few years. All the interview responses were transcribed verbatim. The transcriptions were returned to the interviewees to countercheck the contents. They made corrections to the transcriptions after checking the accuracy.

The observations were carried out for six times during the lessons. Each lesson lasted for 60 minutes. The field notes were returned to some of the participants to countercheck the contents. Triangulation of four research instruments were used to ascertain the reliability of the data. Data were then analysed using Burnard's methods of analysis [40]. In order to embrace qualitative research ethics, the student participants were given pseudonyms. The students were labelled as S1-S12 and the teacher was labelled as T1. 


\section{$4 \quad$ Findings and Discussion}

\subsection{Participants' background information on the use of Internet and social} media

Figure 1 shows the student participants' use of Internet and social media. Despite the different geographical location of where the respondents live, $33 \%$ of the participants have Internet connection at home while another $67 \%$ do not have Internet connection. However, all participants reported to have their own social media account such as Facebook or Instagram. Most of the participants are familiar with social media applications and have experience using them. However, the percentage of frequent Internet users is very small with $16 \%$. This is due to Internet facilities unavailability in the school. It could be concluded that most of the participants are already familiar with the usage of social media in their daily use.

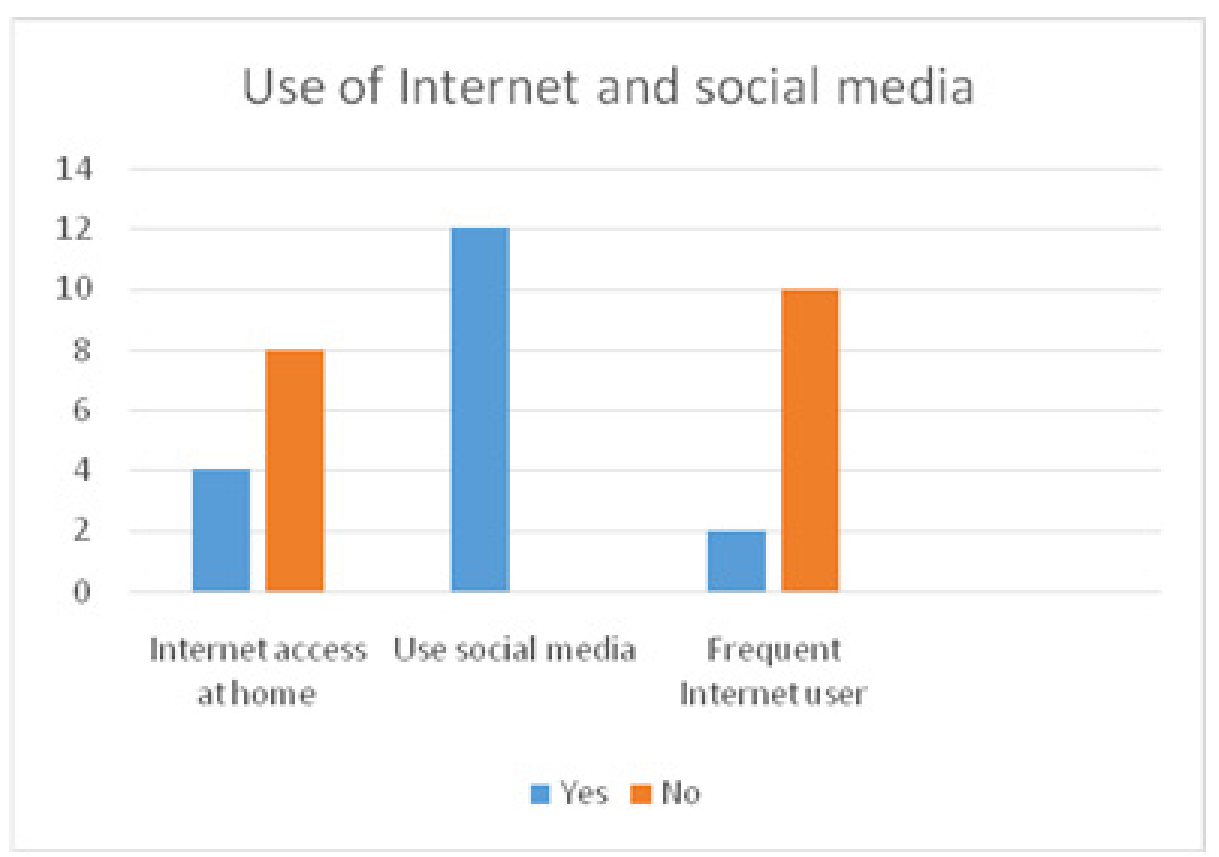

Fig. 1. Student participants' Use of Internet and Social Media

\subsection{What are the perceptions of the teacher and students towards the usage} Google+ in the writing lessons?

This section presents the findings with regards to the abovementioned research question (RQ). In order to answer RQ1, data from the focus group interview (FGI), and field notes and individual interview (CO) were analyzed. Twelve learner participants were interviewed and observed. The teacher was interviewed. The answers to 
this research question are divided into 3 categories; (a) Enable students to learn new knowledge in a more interesting manner, (b) Attractive features, and (c) Enjoyable lessons.

Enable students to learn new knowledge in a more interesting manner. Most participants were excited with the use of Google+ in their writing lessons. This statement is derived from the class teacher's interview responses, focus group interview responses and field notes. Both parties, students and the teacher confessed during the interviews that they loved using Google + , it is beneficial as it has made learning writing skills more fun, enabling them to gain new knowledge by exchanging ideas, retrieving current news, making work easy and enjoyable. Interview responses and observations revealed that, when it was fun, it resulted in them being more alert and less sleepy compared to conventional teaching and learning approach. The student participants added that the process of learning was fun because they could be connected with other students from different schools and countries, and they shared lots of knowledge with each other. The evidence given in the excerpts of interview responses is as follow:

"Emm... For me, using the social network have a good benefits to me. I can know something that I never know before, and also the latest news. I can interact with other people that from other country" (S1, FGI)

"It is more fun because I'm not sleepy" (S3, FGI)

"By using the social media, emm... the learning become more fun, more open, err... the students can connect with other students from different school, err... we can exchange ideas and gain lots of knowledge" (S5, FGI)

For me it can be more fun when using the Google + (S7, FGI)

As for interaction, students were interacting more confidently in Google + writing classes compared to a conventional writing lesson. It was observed that the participants had ample time to revise their ideas and sentences. They had time to generate ideas and evaluate if their ideas could be conveyed through their postings. They had time to check and correct their spelling, sentence structure and tenses too. They also observed and evaluated others' writing in terms of vocabulary, spelling and grammar use. This finding is parallel to [33]. These researchers found that the students had positive attitudes toward using Facebook as a means of learning grammar and writing. As an alternative learning tool, Facebook provided them with a convenient and attractive means to engage in discussions with the teacher and other users who had better grammatical knowledge. In the context of this study, the researcher found that while carrying out group discussions and interaction using Google + , students acquire the motivation and skills related to writing. This can be seen through the postings that the participants made in Google + where they felt convenient to share videos and write comments.

The teacher also brought up during the interview session that teaching writing using Google+ could be resourceful and she also claimed that students work independently to search for information on the internet ("It's really good and it is very resourceful when it comes to lesson, for example when I'm conducting the lesson I'll introduce the students with the topic of the day and quickly the students will browse through the Internet and find information for the lesson") 
Classroom observation $(\mathrm{CO})$ is used to triangulate the data for this section. Figure 2 shows a print screen from the participant interaction during Google+ classroom activities. Participants made full use of the Internet to look for meanings and definition of terms when asked by the teacher. The other participants benefitted from this activity by asking questions and providing their own version of the answer. It was observed that the roles of the teacher are as a facilitator - initiate, probe and also guide the participants to find the suitable answers. Based on the observation notes made by the researcher, this section of the interaction indicates that participants provide the meaning of new words they discovered with the help of Google search. Instead of the teacher providing the meaning and translation, participants helped each other in understanding of terms. The evidence indicates that the participants are independent students.

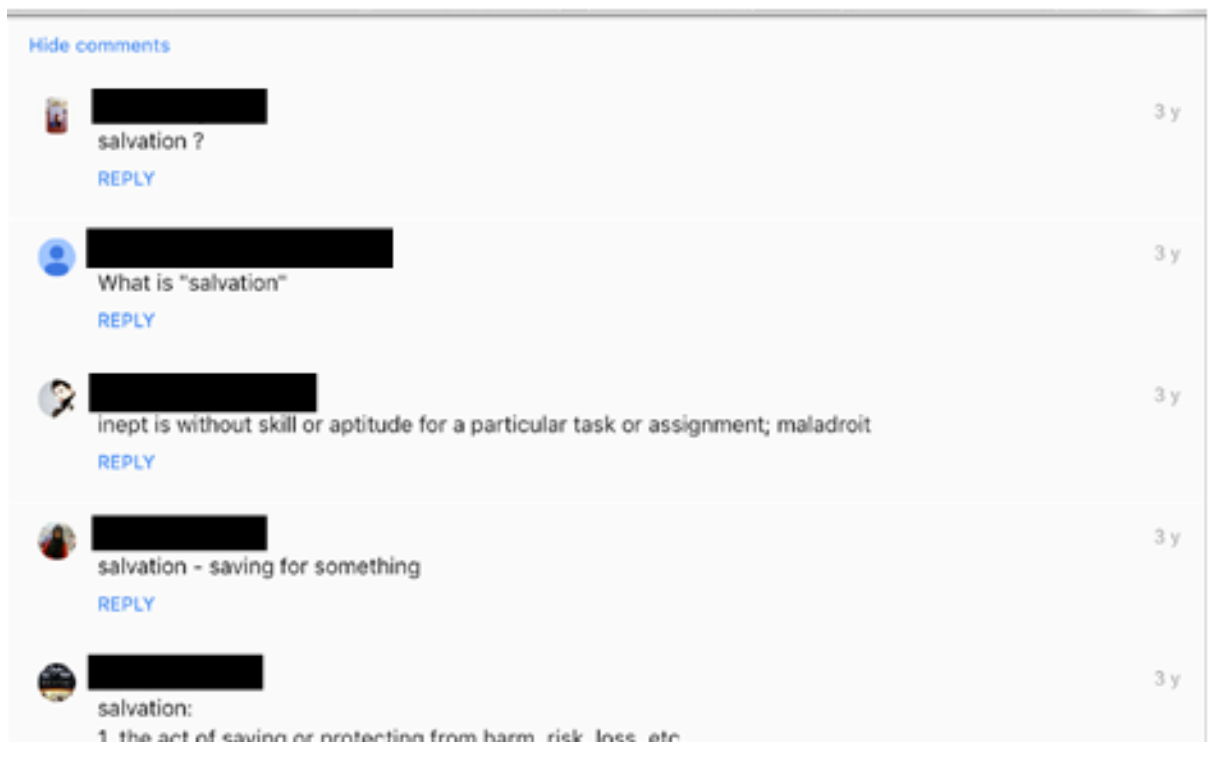

Fig. 2. Participants' interaction on Google+ $(\mathrm{CO})$

The findings of this research show that the use social media in language classroom has been found to reduce stress in a unique, fun and flexible environment, which allows users to access synchronously and asynchronously, this is parallel to the research findings from [29] and [30]. [30] study involved ESL tertiary students in Malaysia. [30] claimed that as second language users the students were afraid of making errors especially linguistic errors. When they read others' postings, they realized that others also faced similar difficulties in writing and made the same errors. Thus, it reduces their stress. The students' apprehension level was also lowered because they complemented and reaffirmed each other's ideas. Moreover, every student had equal opportunity to participate in the discussion. Nobody could monopolize the discussion. Without the absence of facial expression, they would feel less threatened. 
It is safe to conclude that the participants were able to learn more effectively with the assistance of their friends and teachers. By working collaboratively, the students were working in a low stress environment for language practice. The learning environment allows students to work collaboratively to create and share notes.

Attractive features. Most of the participants perceived the features of Google + as attractive. S7 mentioned that Google+ has similar features with other social media apps, for instance, stream, posting and photo sharing.

The researcher further probed the participants with the following question, "What do you like the most about using social media in your class?" Most of the participants preferred the features on video, photos, video chat as they could give comments and post videos related to the topic of learning. The comments and feedbacks helped them to add new ideas in writing. They also felt excited when others 'like' their responses. This is evidenced from the following thread of interview responses.

"When I opened the Internet usually I excited to open the videos shared by others people. I read the status from my others friends and usually I will put my comment there so I will get the respond from my friends. (S1, FGI)

"I like the moment when Miss $\boldsymbol{S}$ showed us the video." (S2, FGI)

"I like the moment when the teachers post or give a topic and err, my friends err, rush to respond to it." (S3, FGI)

"I'm expecting my friends to comment my essay when I post it." (S6, FGI)

"I like the most when my friends and teacher respond to my post. It's good to hear a good response." (S7, FGI)

"I like the moment when my friends and teacher like my post." (S9, FGI)

"I love the moment when I'm watching video and when my friends respond to my post or my comment." (S10, FGI)

During the observations, the researchers noted that one of the features of the Web 2.0 tools where the "read-write" tools enhanced interactivity of the users. Unlike in conventional writing lessons, the only reader of the students' writing is the English class teacher. Generally, the teacher would correct their errors and marked in red ink pen. Web 2.0 is a "read- write" medium, where users contributed their own materials and displayed their creativity as opposed to the "read-only" web where users engage passively with others' content. During the observations, the participants were actively engaged in writing and kept on 'likeing' their classmates' posting. This indicates that the participants put effort in reading others' postings. Some would put emoticons to indicate their feelings in response to others' postings. From the students' facial expressions too, they displayed the eagerness of waiting for others' reply.

Enjoyable lessons. Another main perception put forth by the participants is Google + has promoted enjoyable lessons. They were less sleepy in class. As a result, they became more alert in class. Participants also claimed that they found the lessons more interesting and looked forward to the next lesson. From the focus group interview, individual interview and classroom observations, all participants responded that they enjoyed the writing lessons, as stated by Participant 1 in the Focus Group Interview:

"Yes, I enjoy learning English by using Google+" (S1, FGI)

According to this participant, S1, she became less sleepy and less bored in class, 
"I get less sleepy in the class too and I will get more interesting than before. I feel not too bored during in the class" (S1, FGI)

Other participants also felt the same way as they were less sleepy and alert during writing lessons unlike during the conventional teaching in which the students are more passive in their learning. For example, the responses mentioned by Participant 2 and 4 ,

"Yes, I enjoy it now because before I know Google+ I feel bored during lessons." (S2, FGI)

"Err, I enjoy, because err, using the Google+ I less sleepy and alert toward the class" (S4, FGI)

The data above also supported by the individual interview with the teacher also supported the claims that students enjoyed the writing lesson, as the lessons became more interesting.

"Err, I enjoy teaching writing lesson using the Internet like Google+. Previously we used to teach writing lesson during class hour normally, using text book and other books, so when I use Google+, it is err, much more interesting, because, err, the students get to err, find ideas, information about the topic which they are going to write through the Internet." (TI)

It was evident during the observations that the participants enjoyed the writing lessons using Google+, As a result, they became more confident in giving answers because they could search for information immediately through the use of Google Tools. From the observations, the researchers could see that the participants used multiple sources including YouTube, images, e-dictionaries and other relevant websites. They observed how an unfamiliar word is used in various sentences. They also displayed their excitement when their friends responded and confirmed their answers. Their output was more meaningful because they had authentic readers. These findings concurred with [34] claim. He claimed that language students learning through new technologies can produce meaningful output. When students find learning meaningful, they could gain more output from the lesson.

\section{Conclusion}

The objective of this study was to investigate ESL students' and teacher's perceptions on the use of Google + towards ESL writing lessons. Data were collected using a Focus Group Interview, an individual interview, classroom observation, and document analysis. The answers to the research questions indicate that the use of Google+ has helped students and the teacher in writing lessons in three aspects: knowledge generation, attractiveness of learning environment, and enjoyment. One of the major findings is that the students were able to learn new knowledge in a more interesting manner. Engaging students via Google+, students have a sense of audience when they write on Google+. They also get to give feedback on what other students posted. The attractive features namely stream, photo sharing and posting enable the students to learn more meaningfully and collaboratively. Google+ offers a lot of attractive features for students. They also gained a number of benefits, which include: improving 
IT skills and generate creative writing, having enjoyable and attentive lessons. In addition, the students felt that the writing lessons are more enjoyable. When they have a sense of purpose in writing, they become more engaged in the writing tasks. Having more writing practice also boosted their motivation. As for interaction, students were interacting more confidently in Google + writing classes compared to conventional writing lessons.

The use of Google+ in this study was not only restricted to get students to interact with each other, as it could also be used as a medium by the teacher to monitor the students' progress, especially in ESL writing. Google+ can be used for Learning Management System (LMS) as practiced in many higher institutions of learning. With Google+, teachers can cater to the needs of different levels of students, thus allowing students to develop at their own pace. This is quite difficult to be implemented in conventional teaching especially when the teacher has to teach students from different levels of proficiency. Furthermore, another possibility that Google+ could facilitate English language teacher is by promoting flipped classroom. The flipped classroom is a pedagogical model in which the typical lecture and homework elements of a course are reversed. Short video lectures are viewed by students at home before the class session, while in-class time is devoted to exercises, projects, or discussions. Using Google+, even when the teacher is away, the learning could still take place. The role of a 21 st Century teacher has changed dramatically. Teachers are no longer the sole knowledge provider for the students. With Google+, teachers become the facilitators who guide the students to search for knowledge. It is possible for the teachers to practice the new role and at the same time lead students to take the responsibility for their own learning.

\section{References}

[1] Maslawati Mohamad. "Inovasi Pengajaran dan Pembelajaran Mengoptimumkan Pembelajaran Pelajar”. Dewan Bahasa dan Pustaka. Kuala Lumpur. pp. 199-220, 2017.

[2] Baird, Derek E., and Fisher, M. "Neomillennial User Experience Design Strategies: Utilizing Social Networking Media to Support 'Always on' Learning Styles.” Journal of Educational Technology Systems, vol, 34, issue 1, pp. 5-32. doi:10.2190/6WMW-47L0-M81Q12G, 2005.

[3] Dabbagh, N., \& Kitsantas, “A. Personal Learning Environments, social media, and selfregulated learning: A natural formula for connecting formal and informal learning." The Internet and higher education, vol. 15, issue 1, pp. 3-8, 2012. https://doi.org/10.1016/ j.iheduc. 2011.06.002

[4] Kern, R., Ware, P., \& Warschauer, M. "Network-based language teaching". In N. V. Deusen-Scholl \& N. H. Hornberger (Eds.), "Encyclopedia of language and education", 2nd Edition, vol. 4: Second and foreign language educationNew York: Springer. pp. 281-292, 2008.

[5] Purcell, K., Buchanan, J. \& Friedrich, L. "The Impact of Digital Tools on Student Writing and How Writing Is Taught in Schools." Pew Research Center. From http://pewinternet.org/Reports/2013/Teachers-technology-and-writing, 2013. 
Paper-Secondary School Students' Perceptions on the Use of Google+ towards improving ESL Writing...

[6] Harwati Hashim, Melor Md Yunus \& Mohamed Amin Embi. Pre-University English as Second Language (ESL) Learners' Attitude towards Mobile Learning, Creative Education, vol. 7, issue 8, 2016.

[7] Hiradhar, Preet. "Enhancing ESL Learners' Writing through Technology," International Proceedings of Economics Development and Research. pp. 30-36, 2013. https://doi.org/10.7763/ipedr

[8] Selwyn, Neil. "Social Media in Higher Education." The Europa World of Learning. Routledge, 2012.

[9] Yunus, M. M. Malaysian ESL teachers' use of ICT in their classrooms: expectations and realities. ReCALL, vol. 19, issue 1, pp. 79-95, 2007. https://doi.org/10.1017/S095834 4007000614

[10] Ghavifekr Simin \& Ibrahim Mohammed Sani. "Effectiveness of ICT Integration in Malaysian Schools: A Quantitative Analysis." International Research Journal for Quality in Educatio, vol. 2, issue 8, pp. 1-12, 2015.

[11] Chapelle, C. Computer Applications in Second Language Acquisition. New York: Cambridge University Press, 2001. https://doi.org/10.1017/CBO9781139524681

[12] Cox M. J. and Marshall G., Effects of ICT: Do we know what we should know?, Education and Information Technologies, vol. 12, issue 2, pp. 59-70. 2007 https://doi.org/10.1007/s10639-007-9032-x

[13] Collins, G., Koning, M., \& E van de Velde. “Another Way for Student Exchanges: A Google + Community for Collaborative Learning Related to European Public Health Issues." COHEHRE 2016, 2016.

[14] Saadiyah D. S., Luin H. W. "Investigating Teachers'use Of Computers In Teaching English: A Case Study". Teaching English with Technology, vol. 8, issue 1, 2008.

[15] Lau, B.T., \& Sim, C.H. "Exploring the Extent of ICT Adoption Among Secondary School Teachers in Malaysia", vol. 2, issue 2, pp. 19-36, 2008.

[16] Malaysia Education Blueprint 2013-2025. Available at www.mohe.edu.my, 2013.

[17] Normazidah Che Musa, Koo Yew Lie, and Hazita Azman. "Exploring English Language Learning And Teaching In Malaysia" 12 (January): 35-51. GEMA Online ${ }^{\text {TM Journal of }}$ Language Studies, vol. 12, issue 1, 2012.

[18] Kellogg, R.T. "Writing Skills 1.” Psychonomic Bulletin \& Review. Production Number RCE709, 2006.

[19] Jun, Z. "A Comprehensive Review of Studies on Second Language Writing" 12. HKBU Papers in Applied Language Studies, vol. 12, 2008.

[20] Myles J. Second language writing and research: The writing process and error analysis in student texts. Tesl-Ej, vol. 6, issue 2, pp. 1-20, 2002.

[21] Bello T. Improving ESL Learners' Writing Skills. ERIC Digest. 2007.

[22] Selwyn, Neil. "Social Media in Higher Education." The Europa World of Learning. Routledge, 2012.

[23] MySpace

[24] Facebook

[25] Diallo, Abdoulaye. "The Use of Technology to Enhance the Learning Experience of ESL Students." Online Submission, M.Ed. Thesis, Concordia University. From https://eric.ed.gov/?id=ED545461, 2014.

[26] Power, I.A. "Google + : A Boost To E-Learning Education \& Training @ Covenant University." In EIE's 2nd Intl' Conf.Comp., Energy, Net., Robotics and Telecom.| eieCon2012, pp. 57-68, 2012. 
[27] Curran K, Morrison S, Mc Cauley S. "Google+ vs Facebook: The Comparison." TELKOMNIKA (Telecommunication Computing Electronics and Control), vol. 10, issue 2, pp. 379-88, 2012. https://doi.org/10.12928/telkomnika.v10i2.814

[28] Melor Md Yunus, Hadi Salehi, and Chen Chenzi. "Integrating Social Networking Tools into ESL Writing Classroom: Strengths and Weaknesses Integrating Social Networking Tools into ESL Writing Classroom: Strengths and Weaknesses." Canadian Center of Science and Education, vol. 5, issue 8, pp. 42-48. doi:10.5539/elt. v5n8p42, 2012.

[29] Mohamad M, Shaharuddin S. "Online forum discussion to promote sense of learning community among the group members". International Education Studies, vol. 7, issue 13, pp. 61-74, 2014. https://doi.org/10.5539/ies.v7n13p61

[30] Tarantino, Kristen, and Jessica Mcdonough. "Effects of Student Engagement with Social Media on Student Learning : A Review of Literature." The Journal of Technology in Student Affairs (2013) pp. 1-13. From http://studentaffairs.com/ejournal/Summer 2013/ EffectsOfStudentEngagementWithSocialMedia.html, 2013.

[31] Cequena, M.B. "Does Blogging Facilitate the Development of Students' Writing Skills?" Philippine ESL Journal, vol. 10, pp. 126-47, 2013.

[32] Suthiwartnarueput, T., \& Wasanasomsithi, P. "Effects of Using Facebook as a Medium for Discussions of English Grammar and Writing of Low-Intermediate EFL Students", vol. 9, issue 2, pp. 194-214. Electronic Journal of 104 | PASAA Vol. 52 July - December 2016 Foreign Language Teaching 2012, vol. 9, issue 2, pp. 194-214, National University of Singapore. From http://e-flt.nus.edu.sg/v9n22012/suthiwartnarueput.pdf, 2012.

[33] Chartrand, R. "Social Networking for Language Learners : Creating Meaningful Output with Web 2.0 Tools." Knowledge Management \& E-Learning: An International Journal, vol. 4, issue 1, pp. 97-101, 2011.

[34] Odom, S.F., Holly, D.J., Sandlin, M.R., \& Peek, C. "Social Media Tools in the Leadership Classroom: Students' Perceptions of Use.” Journal of Leadership Education, vol. 12, issue 1, pp. 34-53, 2013. https://doi.org/10.12806/V12/I1/34

[35] Rockinson-Szapkiw, A.J. \& Szapkiw, M. "Engaging Higher Education Students Using Twitter," pp. 360-64. Proceedings of Global Learn Asia Pacific 2011, 2011.

[36] Tække, J., \& Paulsen, M. "The Challenge of Social Media - between Prohibition and Indifference in the Classroom," vol. 1, issue 19. Conference Paper for the Thirteenth Annual Convention of the Media Ecology Association: The Crossroads of the Word. $7 \neg 10$ June 2012 Manhattan College Riverdale, New York, 2012.

[37] Ho-Abdullah I, Hashim RS, Jaludin A, Ismail R. Enhancing opportunities for language use through web-based social networking. Action research. 5. 2006.

[38] Wang, Q., \& Chen, W. "The Effects of Social Media on College Students." MBA Student Scholarship, 2011.

[39] Sitthirak, C. "Social Media for Language Teaching and Learning." Thammasat Journal, vol. 31, issue 1, 2012.

[40] Burnard P, Gill P, Stewart K, Treasure E, Chadwick B. Analysing and presenting qualitative data. British dental journal, vol. 204, issue 8, pp. 429, 2008. https://doi.org/10.1038/ sj.bdj.2008.292

\section{$7 \quad$ Authors}

Maslawati Mohammad is member of Asia Association of Computer-Assisted Language Learning Association (AsiaCALL). She currently serves as a senior lecturer in the National University of Malaysia (UKM). 
Paper-Secondary School Students' Perceptions on the Use of Google+ towards improving ESL Writing...

Naiman Ghazali is a teacher at Sekolah Menengah Sains Setiu, Terengganu, Malaysia. He has 18 years of teaching experience in teaching English as a Second Language (ESL) at secondary school.

Harwati Hashim is a lecturer at the National University of Malaysia (UKM). She is a member of Mobile Learning Association Malaysia.

Article submitted 20 February 2018. Resubmitted 17 April 2018. Final acceptance 18 April 2018. Final version published as submitted by the authors. 